\title{
Discussion on the Improvement of Management Mode of Student Sta- tus in Colleges and Universities
}

\author{
Xiang Li* Dan Zhang \\ Panjin Vocational and Technical College, Panjin, Liaoning, 124000, China
}

\section{ARTICLE INFO}

Article history

Received: 1 April 2021

Revised: 7 April 2021

Accepted: 9 April 2021

Published Online: 16 April 2021

Keywords:

University

Bloodstain management

Improvement

Problem

Main content

Effective measures

\section{Introduction}

The current teaching management in colleges and universities, one of the most important tasks is managing student status. Only students manage their studies well, maintenance of teaching order, the basic situation of students in colleges and universities and the actual effect of teaching are grasped in time, is more important. At present, the speed of new curriculum reform in colleges and universities in China is accelerating, enrolment is expanding, and the amount of information is increasing, this is the process of managing the student status of the relevant teachers, with a lot of pressure.

\begin{abstract}
In order to improve the management of university status in China, it is necessary to actively transform the student status management model, it should be student service, and it's turned into restraint and motivation, the mode of student service as a supplement is transformed. Under the model of service and constraint and incentive, we should strengthen the current management mode of student status in colleges and universities. And under the new model, the data quality of student status can be guaranteed, so that students' academic safety and education and teaching order can be improved accordingly, establish a good learning atmosphere, strengthening management. This paper analyzes and probes into the problems existing in the management of university status in China, this paper expounds the main contents of university student status management, and put forward the effective measures to improve the current management of university status.
\end{abstract}

\section{Current Problems in the Management of Student Status in Colleges and Universities}

At present, china's higher education law in the process of management implementation, teaching ideas and ideas have changed greatly. For teaching plans, teaching model and curriculum construction have higher requirements, therefore, the management of university status in China needs to be improved accordingly, however, there are many problems in the management of student status in colleges and universities, unable to adapt to the current development of modernization. Besides, traditional Management Mode and Means of Student Status, will cause a

\footnotetext{
*Corresponding Author:

Xiang Li,

Female, master's degree, research intern;

Employment Office, Panjin Vocational and Technical College, Panjin, Liaoning, 124000, China;

Research direction: college students' employment and entrepreneurship;

E-mail:308164675@qq.com.
} 
lot of manpower and material resources to be consumed, it has a direct influence on the order of teaching and problems in teaching reform ${ }^{[1]}$.

\subsection{Lower Means}

At present, China's student status management methods are relatively backward, most of the time, will choose to use manual operation mainly, information that causes feedback to lag, unordered state of management, this leads to inefficient states, causes duplication of labor, have a large workload, accuracy also has some problems, can not meet the current development of modern teaching, the effect of teaching management is weakened. exempli gratia, student at a certain university enters school, first registration, until the end of the graduation process, about dozens of projects need to be recorded, more information and tables are involved ${ }^{[2]}$. So if you rely solely on manual manipulation, can lead to inefficient problems, prone to negligence, causes errors.

\subsection{Lower Quality of Managers}

Due to the management of student status, is a more complex task, there will be a lot of work, there are more factors, so this requires managers to spend a lot of time and energy dealing with the corresponding problems. Just literally, some simple work on student status management. However, in fact, the management of student status is that colleges and universities in our country hope to educate students through student status, therefore, at present, the quality of our managers needs to have a higher level ${ }^{[3]}$. However, at present, the quality of staff in the management of student status in Chinese colleges and universities is low, educational institutions are not reasonable, most people are not trained professionally, and in recent years, the enrollment of colleges and universities in China is expanding, so the number of students is increasing, and managers are in short supply.

\subsection{The Management Mechanism Is Not Perfect}

At present, the number of college students is increasing, and the forms of running schools are also diversified, this complicates the issue of student status. For example, some general undergraduate students need to carry out corresponding student status management, there are also special promotion and higher vocational college students need to carry out the corresponding student status management, therefore, the current management system of university status does not speed up the reform, will lead to problems in student status management ${ }^{[4]}$.At present, China's modernization is accelerating, the traditional management mode of student status can not satisfy the development of modernization. In addition, colleges and universities in the national enrollment line is not consistent, so in a university, the existence of a poor number of copies, this is the basis of learning and learning ability of high school students there are increasing differences. Therefore, the current reform of the management of student status in China, problems need to be taken into account.

\section{Main Contents of Current Management of Student Status in Colleges and Universities}

At present, the main contents of the management of student status in Chinese colleges and universities are, registration information at the time of admission, basic personal information, and records of changes in student status, incentives and penalties for students in higher education, entry and verification of student test scores, students' graduation qualification and certificate issuance. And good student status management, it can improve the quality of talents in colleges and universities ${ }^{[5]}$.Strengthening the Management of Student Status in Colleges and Universities, it can improve students' learning motivation, to ensure that students can develop smoothly according to the efficient talent training program, so that students can graduate smoothly. Besides; in addition, strengthening Student Status Management in Colleges and Universities, it can help establish the style of study in colleges and universities, to regulate students' daily behavior, building a Good Style of Study, implementation of the talent program.

\section{Effective Measures to Improve the Man- agement of Student Status in Colleges and Universities}

\subsection{To Perform Duties of Managing Student Sta- tus Based on Service}

\subsubsection{Strict Control of Enrollment Registration, for Freshmen to Do a Good Data Review}

New students after admission, student status management staff are required to review students' admission qualifications, and the machine can be the corresponding electronic registration of student status. So colleges and universities need to strengthen the control of student enrollment, you can establish two levels of audit at the hospital level and at the school level. Where the college was conducting the audit, students need to be compared with electronic photos, and the material in the file is consistent, 
for students with some problems, communication and verification required, strict review of new students' enrolment needs, prevention of impersonation. Aside, in the school audit, review of admission data is required, strengthen investigation on duplicate and duplicate issues, if there's a problem, first, you need to suspend registration, after identification ${ }^{[6]}$.And at the time of review, the school re-examines the photos and ID information examined, confirmation information; Students themselves should check the admission information, it's time to check, student needs to sign confirmation, after confirmation, this information will serve as the basic data for the electronic registration of student status.

\subsubsection{Enhance Process Management and Expand the E-Registration Function for the Academic Year}

In recent years, some colleges and universities in China are constantly exploring the routine work of electronic registration, and divide it into the current work system of supervision and management of students, making management work. For example, school early warning management, survey of students' comprehensive academic status, it is the extension of the current student electronic registration work. When specific work is under way, don't implement one-click registration, and according to the process and time of the work, to complete the corresponding registration task ${ }^{[7]}$. And for student status changes, a reasonable distinction should be made, cancellation of some student status, the approval system should be implemented, departments and leaders in colleges and universities, in order to complete the corresponding write-off task. And for suspension or re-study and other changes in the situation, need to be based on actual structure, timely marking, do a good job, promoting the development of student status management in Chinese Universities.

\subsubsection{Do a Good Job of Fine Exit Supervision and Management to Ensure the Quality of Academic Registration}

At the time of the export control, universities need to strengthen the quality of student status data, universities need to strengthen the quality of student status data accuracy. There is a need to regularly check the blood of the students in the school, implementing export control into daily management. And after graduation, the school should conduct an information check on the status, final check of the student status information, when you find a problem, it should be handled in a timely manner, after there is no problem with security, to employment and ed- ucational services. And with the establishment of school informatization, colleges and universities should also choose the way to use information, enable students to use online platforms or WeChat public numbers, you can query your student status information in time, combine old and new ways organically, give full play to their own advantages to ensure the quality of export data ${ }^{[8]}$.

\subsection{Enhancing Process Constraints and Safety Control of Aggregated Studies}

\subsubsection{Revise the Management Mode of Trial Reading and Dropping out of School, and Estab- lish the Restraint Mechanism of Academic Early Warning and Elimination}

At present, through a survey of student status management in colleges and universities, it can be seen that there are problems and risks in student status information, most of it is due to the failure of the examination to meet the current school standards. And in the traditional way, although it can solve some students' problems, but in practice, there will be new problems, Management is also prone to problems, as a result, the restraint ability of student status management is reduced. Therefore, the current school to try to read and drop out of the management of the, for example, humidity needs to be downgraded, each student can only be demoted twice at most, and if a student has problems, withdrawal should be undertaken, establish academic early warning elimination mechanism to restrain students.

\subsubsection{Change the Contents of the Registration Form and Establish the Restraint Mechanism of the Integrity File}

In the management of students' academic safety, colleges and universities, colleges and universities should be Irrational to the existential management, and some empirical measures exist in the unreasonable part of the effective improvement, and innovation. Schools need simple corrections to some basic information, and the registration form in the integrity of the record of the corresponding changes, and reward and punish the student's actual performance of students, and the registration of the student's grant or application status at the school. In addition, for the student status information registration form, More details to be recorded, in particular, there are parts about integrity, schools strengthen elm, establish integrity file restraint mechanism. 


\section{Conclusion}

For our college teaching management, students' status management is a very important content, this is a longterm and requires more detailed work. Therefore, colleges and universities need to reform the student status management system, only the traditional management model is transformed, match the current modern development model, use of efficient management tools, in order to promote the development of current student status management system and cultivate innovative talents in colleges and universities in China.

\section{References}

[1] Duan Xiaocong. Discussion on Student Status Management in Applied Undergraduate Colleges under Credit System Management Mode [J]. Science and Technology Vision, 2017(23):33-34.

[2] Zhang Tingting. A Study and Practice on Academic Early Warning Mechanism and Aid Work of Student Status Management in Colleges and Universities [J]. Vocational skills, 2017, 16(6):54-55.

[3] Jiang Weimin. Based on. The Design and Implementation of NET Student Management System in
Higher Vocational Colleges [J]. Journal of Heilongjiang Vocational College of Ecological Engineering,30(3):39-42.

[4] Xiong Jing, Bai Kai. A Summary and Discussion on Some Experiences in the Management of Student Status in Colleges and Universities [J].2018, 235(13):168-169.

[5] Dilliping, Chen Chaodong, Niu Jianren. Reflections on Teaching Assistant Management in Colleges and Universities Based on Internet+ $[\mathrm{J}]$. Higher Education Development Studies, 2017(34):48.

[6] Qiao Yuqiong. A Discussion on the Innovation Mode of College Counselors' Management Based on the Concept of Student Development [J]. Technology Information, 2017, 15(9):182-182.

[7] Chen Zheng, Lu Yan, Wang Wenjun, et al. On the Problems and Improvement Strategies in the Management of Student Status in Colleges and Universities — Taking Xinjiang Agricultural University as an example [J]. New West, 2017(11):39-40.

[8] Baiyun Tao, Liu Zhentao. Discussion on the Mode of Employment in Colleges and Universities under the background of "Internet" era [J]. South farm machinery, 2018, 304(12):12. 